\title{
SHY-DRAGER SYNDROME
}

\author{
A CASE REPORT WITH POLYSOMNOGRAPHY
}

F. S. ALOE $*$ - P. E. MARCHIORI*-R. N. REIMAO* - M. SCAFF*

SUMMARY - The authors report a case of Shy-Drager syndrome in a 53 year-old male patient. Autonomic failure was made evident by physical examination us well as laboratory tests. A sleep recording showed decreased percentage of REM sleep and apneas of the central type. The possible mechanisms for this sleep disorder are discussed.

\section{Sindrome de Shy-Drager: registro de caso com estudo polissonográfico.}

RESUMO - relatado o caso de um paciente de 53 anos de idade com diagnóstico de sindrome de Shy-Drager. Testes laboratoriais e exame físico evidenciaram claramente o distúrbio do sistema nervoso autônomo. Foi também obtido traçado poligráfico do sono durante uma noite completa, que mostrou diminuiçào do sono tipo MOR e apnéias do tipo central. Os possiveis mecanismos destes achados polissonograficos são discutidos.

It was first in 1960 that Shy and Drager described two patients with autonomic failure associated with other neurological deficits 28 . Much has been published in medical literature in the recent years but only a few papers have devoted some attention to sleep disorders in patients with autonomic failure.

The case reported in this paper shows a certain number of sleep changes associated with autonomic failure.

\section{CASE RFPORT}

NRS, a 56 year-old white married male originally born in Londrina (Paraná) was admitted to HCFMUSP on 12-08-1987 with a history of repeated faintins spells and sexual impotence. He was originally seen at his home town when he was given antihypertensive drugs because of an increased arterial blood pressure. No improvement was recorded and the: patient begun to experience pain and muscle weakness in the lower limbs. He was operated on a possible herniated cervical disk two months later. Shortly after he began to show urinary urgency, fecal retention and the fainting spells became more frequent. He was unable to stand up because of a dizziness sensation associated with paleness, nausea, vomiting and mental confusion with sometimes brief loss of consciousness unaccompained by sphincteric $c J$ other motor manifestations. He also referred a dry mouth, muscle wasting, weight loss, dry skin, tremor and a gait disturbance in the last months. His past medical records were vuremarkable. A family history of fainting spells in two daughters after vigorous exercice was obtained. At admission his physical examination yielded a somewhat anxious man. His skin was pale and dry. Supine blood pressure was 18/11 cmHg with a pulse rate of $84 \mathrm{bpm}$. After standing up for two minutes his blood pressure wus $13 / 9 \mathrm{cmHg}$. In 5 minutes he began to feel dizzy becoming confused, his skin became paler and recorded

* Divisão de Neurologia, Hospital das Clínicas da Faculdade de Medicina da Universidade de São Paulo (HCFMUSP).

Dr. Flavio s. Aló - Divisão de Nentrologia, Hospital das Clínicas, E'MUSP - Caixa Postal 
blood pressure was $0 / 0 \mathrm{cmHg}$ with a pulse rate of $88 \mathrm{bpm}$. Prompt relief was achievad at the supine position. The remaining of his physical examination was unremarkable. His neurological exemination yield a cerebellar syndrome with action tremor, past pointing predominating in left arm; a pyramidal syndrome characterized by decreased muscle power predominating in the lower limbs, hyperactive deep tendon rellexes with Babinski reflex and Hoffman sign bilaterally present and an ankle clonus; a frontal syndrome characterized by hyperactive nasopalpebral, ororbicular, palmomentual reflexes; an autonomic syndrome characterfzed by sexual impotence of the coeundi type, a neurogenic bladder, decreased sweating and intestinal obstipation. Fundoscopic examination as well ats pupillary reflexes were normal. A routine laboratory survey disclosed a hemoglobin of $10.4 \mathrm{~g} / \mathrm{dl}$ a $\mathrm{RBC}$ of 3870000 cells $/ \mathrm{mm}^{3}$, WBC of 7900 cells $/ \mathrm{mm}^{3}$ and 200000 platelets $/ \mathrm{mm} 3$. BUN was normal, Na of $135 \mathrm{mEq} / 1$ alui $\mathrm{K}$ of $3.5 \mathrm{mFq} / 1$ and a fasting glucose of $83 \mathrm{mg} \%$. Serum protein electrophoresis, plasma cortisol, thyroid hormones, hepatic enzymes assay were normal. CSF analysis with protein electrophoresis and reations for syphilis, neurocysticercosis were negative. An urine culture was positive for «Pseudomonas aeruginosa》. A chest film and an FKG were normal, A CT scan was performed with no abnormal findings recorded. An entire night sleep record was obtained and the results are as follows: a sleep efficiency of $62 \%$ with a marked reduction of REM sleep. Apneas of the central type were recorded throughout the night lasting from 10 to 23 seconds with no change in heart rate during or after the apneic periods. The patient was requested to wear elastic stockings and was put on a combination of $150 \mathrm{mcg} / \mathrm{day}$ of 9-alpha-fluor-hydrocortisone, $0.8 \mathrm{mcg} / \mathrm{day}$ of clonidine and $150 \mathrm{mg} / \mathrm{day} \mathrm{ergot}$ alcaloid. He became able to stand up again with a blood pressure of $7 / 4 \mathrm{cmHg}$ attended by a heart rate of 140 with no symptoms of decreased cerebral flow.

\section{COMMENTS}

It was in 1925 that for the first time Bradbury and Eggleston 1,3,28 described a series of three patients with symptoms of orthostatic hypotension associated with a failure to increase the heart rate. In 1960 Shy and Drager 3,28,29 described two patients with orthostatic hypotension unattended by an increase in heart rate, anhydrosis, sphincteric disturbance, iris atrophy, associated with other somatic neurological deficits. Much has been published about autonomic failure associated with other neurological symptoms such as cerebellar, extrapyramidal or pyramidal deficits 3-5,7-9, $\mathbf{1 1 , 1 2 , 1 4 , 1 5 , 1 8 , 2 1 , 2 7 - 2 9 , 3 5}$. In a broader sense Shy-Drager syndrome can be defined as an autonomic nervous system failure of the central type $3,5,8,9,14,16,17,22,32$ characterized by preganglionic degeneration. Normal or slightly higher norepinephrine levels in the peripheral blood at the resting supine position and a failure to increase upon standing are characteristically found $\mathbf{1 6 , 1 7 , 2 3 , 3 2}$. A normal or slightly above normal hypertensive response to norepinephrine infusion and a positive response to tyramine administration show a degeneration of the central type with normal receptor affinity 16,17,35. Pathologically there can be cellular degeneration in the intermediolateral column, anterior horn cells, basal ganglia, solitary tract nucleus, vagal dorsal nucleus, substantia nigra, locus coeruleus, cerebellar tracts, corticobulbar and corticospinal tracts $1,26,29,30,33,34$.

Autonomic nervous system tests such as Valsalva's manuever, sweating tests, cold pressor and, mental stress pressor tests, atropine, amyl nitrate and norepinephrine drugs tests are altered in most cases of Shy-Drager syndrome 8-10,20,24,25,29. The clinical picture is one of affecting men in the age range of 35 to 75 years with a mean onset at the age of 55 . Sex ratio is 2 or $3: 1$ male to female $3,24,25,29,30$. An insidious presentation with a protracted course over months or years with a few rare cases of an abrupt onset is the general rule $3,7,12,14,24,28,30$. Autonomic symptoms are then followed by other somatic neurologic symptoms in average 4 to 5 years later. Death usually occurs on an average of 7-8 years after disease onset and 4-5 years later to somatic symptoms appearance $3,24,25,29,30$.

The case reported here qualified for the diagnosis of Shy-Drager syndrome $3,28,29,31$. However, other neurological disorders can be initially manifested by an orthostatic hypotension. Only one disorder may be relevant in this paper as part in the differential diagnosis. Primary orthostatic hypotension is also a degeneration of the autonomic system of the peripheral type 4,5,7-10,16,17,23,29,30,32,35. Characteristically low levels of norepinephrine are found in the resting supine position as well as a failure to increase upon standing $16,17,35$. A challenge with tyramine will result negative $9,10,24,25,32$ but extraneous norepinephrine will provoke an hypertensive response displaying thus a degeneration of the postsynaptic neurons with ensuing receptor hypersensitivity. 
The condition is a benign one with better prognosis and is invariably unattended by other somatic neurological symptoms 1,2,29,30,32. Only a few reports have so far addressed attention to sleep disorders in patient with autonomic failure of the central type 19. Some authors have reported an apnea of the obstructive type due to vocal paresis or hypopharynx muscle hypotonia 13 . Other reports have shown sleep paralysis and myoclonus. It is the authors understanding that the two latter disorders are coincidental. Lehrman et al.19 have shown a patient with Shy-Drager syndrome with apneas of the obstructive type in which pulmonary hypertension still occurred despite the fact of the autonomic failure to mediate the cardiovascular response to hypoxia. He believed that local mechanisms could account for these responses. It is our belief that the autonomic dysfunction present in the reported patient could be an underlying cause for the sleep finding. It is well known that in Shy-Drager syndrome there is a widespread neuronal loss in the pigmented brain stem nuclei such as substantia nigra, locus coeruleus and vagal dorsal nucleus 1,26,29,30,33,34. It is also known that the locus coeruleus is involved in the generation and mantainance of REM sleep 6 so that a neuronal loss involving this nucleus in Shy-Drager syndrome could account for the decrease in REM sleep. The other feature found in the sleep recordings of the reported case is the central type of apnea. There too, the autonomic failure could account for such a finding. The autonomic pathways involved in the automatic mechanisms of keeping the periodicity of respiration during sleep would be impaired giving rise to apneas of the central type. It is known that the baroreceptor loop is defective in the central type of autonomic degeneration as made clear by the abnormal response of the Valsalva's maneuver $8-10,20,24,25,29$. That can be assumed to some degree for other autonomic reflexes taking part in the physiology of automatic respiration during sleep.

\section{RFFERENCLAS}

1. Bannister If - Degeneration of the autonomic nervous system. Lancet 2:175, 1971.

2. Bannister F;, Mowbray J, Sidgwlck A - Genetic control of progressive autonomic failure: evidence for an association with an HLA antigen. Lancet 1:1017, 1933.

3. Barr AN -- The Shy-Drager syndrome. In PJ Vinken, GWV Bruyn (eds): Handbook of Clinical Neurology, Volume 38. Elsevier, Amsterdam, 1983, fe. 233.

4. Blomqvist CG - Orthostatic hypotension. Hypertension 8:722, 1986.

5. Brevetti G, Chiarello M, Campanella G - Different types of orthostatic hypotension: current concepts. Acta Neurol (Napoli) 5:441, 1983.

6. Brodal B - Neurological Anatomy. Qxford Univ Press, N.3w York, 1969, og 698.

7. Castillo J, Garcia-Martinez I, Lema M, Noya M - Hirotensión orthostátlca crónica idiopática: revisión de conjunto. Rev Clin Esp 5:185, 1982.

8. Cocco G, Strozzi C, Portaluppi F, Tasíni MT, Rizzo A, Alfiero R, Padula A, Montanari L - L'ipotensione ortostatica. Clin Ter 117:133, 1986.

9. Costa C, Marino O, Barletta $R$, Natoli A - Lipotensione ortostatica: attuali conoscenze eziopatogenetiche diagnostiche e terapeutiche. Clin Ter 118:49, 1986.

10. Fouad FM, Tarazi RC, Bravo EL - Orthostatic hypotension: clinical experience with diagnostic tests. Cleveland Clin Q 52:561, 1985.

11. Giroud M, Guard O, Soichot P, Sautreaux JL, Thierry A, Dumas R - Hypotension arterielle orthostatique et aneurysme geant du tronc basilaire. Ann Cardiol Angiol $35: 27,1986$.

12. Gross $\mathbf{M}$, Bannister $\mathbf{R}$, Godwin-Austen $\mathbf{R}$ - Orthostatic hypotension in Parkinson's disease. Lancet $1: 174,1972$.

13. Hanson OG. Ludlow CL, Bassichi CJ - Vocal fold paresis in Shy-Drager syndrome. Ann Otol Luryngol 92:85, 1983.

14. Hohl RD, Frame B, Schatz IJ - The Shy-Drager variant of idiopathic orthostatic hypotension. Am J Med 39:134, 1965.

15. Huelgas RG, Reinoso MEC, Donate JQ, Hernandez GM -- Sindrome de Shy-Drager: descripción de un caso. Rev Clin Esp 176:91, 1985. 
16. Kafka MS, Polinsky RJ, Williams A, Kopin IJ, Lake ZR, Ebert MH, Tokola NS Alpha-adrentrgic receptors in orthostatic hypotension syndromes. Neurology 34:1121, 1984.

17. Kopin IJ, Folinsky RJ, Oliver JA, Oddershede IR, Ebert MH - Urynary catecholamine metabolites distinguish different types of sympathetic neuronal dysfunction patients with orthostatic hypotension. J Clin Endocr Metab 57:632, 1983.

18. Kuroywa $Y$, Shimada $Y$, Toyokura $Y$ - Postural hypotension and low $R-R$ interval variability in parkinsonism, spinocerebelar degeneration, and Shy-Drager syndrome. Neurology 35:463, 1983.

19. Lehrman KL, Guilleminault C, Schroeder JS, Tilkian A, Forno Nl - Sle€p apnea syndrome in a patien: with Shy-Drager syndrome. Arch Intern Med 138:206, 1978.

20. Lorenzini M - Incidenza della ipotensione ortostatica: inäagine clinica su 1010 casi. Min Med 73:3395, 1982.

21. Ruchoux M, Gray F, Gherardi R, Schaeffer A, Comoy J, Poirier J - Orthostatic hypotension from a cerebellar gangliocytoma (Lhermitte Duclos disease): case report. J Neurosury 65:245, 1986.

22. Schatz IJ - Current management concepts in orthostatic hypotension. Arch Intern Med 140:1152, 1950 .

23 Schatz IJ -- Orthostatic hypotension: I. Functional and neurogenic causes. Arch Intern Med 144:773, 1984.

24. Schatz IJ - Orthostatic hypotension: II. Clinical diagnosis, testing, and treatment. Arch Intel'n Med 144:1037, 1984.

25. Schatz IJ, Podolsky S, Frame B - Idiopathic orthostatic hypotension: diagnosis and treatment. J Am Med Assoc 186:537, 1963.

26 Schwarz GA $\rightarrow$ The orthostatic hypotension syndrome of Shy-Drager: a clinico-pathologic report. Arch Neurol 16:123, 1967.

27. Shimizu H, Sumi K, Sugita J, Abe J, Futagi Y, Mimaki T, Yabuuchi H -- Cerebral blood flow changes in orthostatic dysregulation fainters. Brain Dev 4:21, 1982.

28. Shy GM, Drager GA - A neurological syndrome associatd with orthostatic hypotension. Arch Neurol 2:511, 1960.

29. Spalding JMK, Nelson E - The autonomic nervous system. In AB Baker, IAf Baker (eds): Clinical Neurology, Volume 4. Harper \& Row, Philadelphia, 1985, pag 1.

30. Thomas Jis, Schrirger A - Idiopathic orthostatic hipotension: a study of its natural history in 57 neurologically affected patients. Arch Neurol 22:289, 1970.

31. Thomas JE, Schirger A. Fealey RD, Sheps SG - Orthostatic hypotension. Mayo Clin Proc 56:117 1981.

32. Thulesius D - Pathophysiological classification and diagnosis of orthostatic hypotension. Cardiology 61 (suppl, 1):180, 1976.

33. Van Der Haeghen J, Perier O, Sternon JE - Pathological findings in idiopathic orthostatic hypotension: its relationship with Parkinson's disease. Arch Neurol 22:207, 1970.

34 Wagner IIN - Orthostatic hypotension. Bull J Hopk Hosp 105:322, 1959.

35. Ziegler Mir, Lake R, Kopin IJ - The sympathetic nervouz system defect in primary orthostatic hypotension. New Fingl J Med 296:293, 1977. 